\title{
A Medieval European Value for the Circumference of the Earth
}

\author{
C. Philipp E. Nothaft \\ All Souls College, Oxford, UK \\ philipp.nothaft@all-souls.ox.ac.uk
}

\begin{abstract}
Geographic and astronomical texts from late-medieval Central Europe frequently give 16 German miles, or miliaria teutonica, as the length of a degree of terrestrial latitude. The earliest identifiable author to endorse this equivalence is the Swabian astronomer Heinrich Selder, who wrote about the length of a degree and the circumference of the Earth on several occasions during the 136 os and 1370s. Of particular interest is his claim that he and certain unnamed experimentatores established their preferred value empirically. Based on an analysis of relevant statements in Selder's extant works and other late-medieval sources, it is argued that this claim is plausible and that the convention $1^{\circ}=16$ German miles was indeed the result of an independent measurement.
\end{abstract}

\section{Keywords}

medieval geodesy - medieval astronomy - medieval metrology - circumference of the Earth - Heinrich Selder

Regular readers of geographic and cartographic literature printed before 1900 will have come across the concept of the German geographic mile, which was defined as covering one fifteenth of a degree of latitude, making it equivalent to 4 nautical miles. It is possible to trace this definition of the German mile (miliaria teutonica) back to the beginning of the sixteenth century, more specifically to the Margarita philosophica, Gregor Reisch's widely read and frequently printed encyclopaedic textbook (first edition: 1503). In the astronomically themed seventh book of the Margarita, Reisch derives the equivalence of $1^{\circ}$ and 15 German miles from Ptolemy's estimate according to which there are 
500 stades to a degree of latitude and 180 ,ooo stades in the circumference of the whole Earth. He claims that these 180,000 stades are equivalent to 21,600 Italian miles, while 4 Italian miles equal 1 German mile, yielding a circumference in German miles of $5400 .{ }^{1}$ Reisch's neat conversion was aided by his decision not to reckon 8 stades for every Roman or Italian mile, as was commonly done in ancient and medieval sources, but to opt for an alternative relation of 8 1/3 stades equalling 1 Italian mile that was briefly mentioned in Strabo's Geography $(7 \cdot 7 \cdot 4) .^{2}$ This way, he could assert that $1^{\circ}=5$ oo stades $=6$ o Italian miles $=$ 15 German miles, without having to deal with any fractions. The majority tradition of counting 8 stades for each Italian mile instead would have given him a circumference of 22,500 Italian miles and a terrestrial degree of 62 1/2 Italian miles, which was not expressible in a round number of German miles as defined by Reisch. ${ }^{3}$

It is a relatively little-known fact that, prior to the introduction of the German geographic mile just discussed, some scholars in central Europe reckoned not with 15 , but with 16 German miles for a degree of latitude, such that the circumference of the Earth came out as 576o German miles. One of the few modern historians to have paid any attention to this value was Dana Bennett Durand, who observed that conversions based on an equivalence of $1^{\circ}$ and 16 German miles were a common practice among fifteenth-century German geographers. ${ }^{4}$ This impression is indeed confirmed by the words of the Bavarian astronomer Johannes Engel, who in 1512 could still write that each degree "is commonly accepted to be 16 German miles". ${ }^{5}$ Another relevant source from the first quarter of the sixteenth century is a geographical manuscript once in the possession of Johannes Schöner (1477-1547), which includes a conversion table for the number of miles to a degree of longitude at different latitudes, with 16 German miles being the value at $0^{\circ}$. In the margins of this table, the scribe points out that 1 German mile equals 43 3/4 stades, implicitly basing his

1 Gregor Reisch, Margarita philosophica (Freiburg i. Br., 15०3), sig. O5v (bk. 7, tr. 1, c. 44).

2 On the background, see Sarah Pothecary, "Strabo, Polybios, and the Stade," Phoenix, 49 (1995), 49-67.

3 See the discussion in Stefan Kirschner, Andreas Kühne and Felix Schmeidler, eds., Receptio Copernicana: Texte zur Aufnahme der Copernicanischen Theorie (Berlin, 2015), 127-128, where the role played by the length of the stade in Reisch's conversion is effectively ignored.

4 Dana Bennett Durand, The Vienna-Klosterneuburg Map Corpus of the Fifteenth Century: A Study in the Transition from Medieval to Modern Science (Leiden, 1952), 156, 170.

5 Jerzy Dobrzycki and Richard L. Kremer, "Peurbach and Marāgha Astronomy? The Ephemerides of Johannes Angelus and Their Implications," Journal for the History of Astronomy, 27 (1996), 187-237, at 223 . 
assertion on the Eratosthenian estimate of $1^{\circ}=7$ oo stades $(700 \div 16=433 / 4) .{ }^{6}$ Now, it should be clear that this value of 700 stades does not lend itself to the same straightforward derivation that presumably spawned the equivalence of $1^{\circ}$ with 15 German miles. If we follow Gregor Reisch in accepting that 1 Italian mile equals $81 / 3$ stades, then 700 stades come out as 84 Italian miles. For this to amount to 16 German miles, 1 German mile would have to equal 5 1/4 Italian miles, which is not a relation attested in these sources. Things look messier still if 1 Italian mile is made to equal 8 stades, in which case 700 stades equal 87 1/2 Italian miles, implying that 1 German mile is the same as 5.46875 Italian miles.

If this incongruence is one reason to suspect that the relation $1^{\circ}=16 \mathrm{Ger}-$ man miles was originally independent of the Eratosthenian measurement of the degree as 700 stades, another is offered by the simple fact that late-medieval witnesses to this relation tend not to invoke any ancient estimates when stating the number of German miles in a degree. One known author who treated it as basic was Georg Peurbach in his Latin treatise on the comet of 1456: "Experience has taught that 16 German miles lie below one degree in the heavens." ${ }^{7}$ Experience as the basis for accepting this relation is also alluded to in the Instrumentum de distantiis civitatum et regnorum transmitted in a midfifteenth century manuscript from southern Germany, in which it is claimed that "many people have demonstrated" (ut per multos probatum est) that one degree in the heavens corresponds to 16 miles on Earth. ${ }^{8}$ The author's use of the phrase per multos probatum est, vague though it is, may be taken to suggest that some form of empirical confirmation was believed to underpin the equivalence in question. If so, when and by whom was it carried out?

My attempts to answer this question have led me back to an obscure astronomical text in six chapters, which was written in 1366 to accompany a set of tables for the conjunctions, oppositions, and ecliptic longitudes of the Sun and Moon. Its preface begins with the words Benedictus Deus et mater eius gloriosa

6 MS Vienna, Österreichische Nationalbibliothek, 3505, fol. 127r. See Durand, Vienna-Klosterneuburg Map Corpus, 163-164, 168-170.

7 See the text edited in Alphons Lhotsky and Konradin Ferrari d'Occhieppo, "Zwei Gutachten Georgs von Peuerbach über Kometen (1456 und 1457)," Mitteilungen des Instituts für Österreichische Geschichtsforschung, 68 (1960), 266-29o, at 274: "Uni autem gradui circuli magni in celo 16 miliaria Teutonum in terra experiencia subesse docuit." See also the treatise on the comet of 1472 attributed to (but possibly not by) Johannes Regiomontanus, as printed in Jane L. Jervis, Cometary Theory in Fifteenth-Century Europe (Dordrecht, 1985), 196: "Nam uni gradui in circulo magno correspondent 16 miliaria de circumferentia terrae."

8 See MS Munich, Bayerische Staatsbibliothek, Clm 11067, fol. 174v, as printed in Durand, ViennaKlosterneuburg Map Corpus, 344: "Si autem illum numerum iam ultimo inventum multiplicabimus per 16, provenient miliaria theutunicalia, quia uni gradui in celo correspondent 16 miliaria in terra ut per multos probatum est." 
et sanctus Martinus. Quia quidam de amicis meis melioribus... ${ }^{9}$ For the sake of brevity, I shall refer to the work as Conjunctions in what follows. Versions of it survive in the following nine manuscripts. ${ }^{10}$

$\mathrm{Au}$ Augsburg, Universitätsbibliothek, Cod. II.1.4 ${ }^{\mathrm{o}}$ 61, fols. 3 or-35 $\mathrm{r}$ (tables), 35v-39v (text); s. $\mathrm{XV}^{3 / 4}$ (c. 146o)

Ba Bamberg, Staatsbibliothek, Msc. Astr. 4, fols. 55r-64r (tables), 71ra$78 \mathrm{vb}$ (text); s. XIV ${ }^{2 / 2}$

Be Berlin, Staatsbibliothek, theol. lat. qu. 152, fols. 122r-123r (text), 123V-13or (tables); s. $\mathrm{XV}^{1 / 4}$ (c. 1408-1412)

Er Erfurt, Universitäts- und Forschungsbibliothek, Dep. Erf. CA $4^{\circ} 387$, fols. $65 \mathrm{v}-67 \mathrm{r}$ (solar tables), 67v (incomplete text), 97r-101r (tables); S. $\mathrm{XIV}^{2 / 2}$

Ka Kassel, Universitätsbibliothek, Ms. math. fol. 31, fols. 219r-222V (incomplete tables), 223r-v (text); s. $\mathrm{XV}^{1 / 2}$

Kr1 Kraków, Biblioteka Jagiellońska, 562, fols. 36v (text), 37r-43v (tables), 44ra-45ra (text); s. XIV ${ }^{2 / 2}$ (c. 1387)

Kr2 Kraków, Biblioteka Jagiellońska, 1915, fols. 86r-91r (tables), 91v-92V (text); s. $\mathrm{XV}^{\text {in }}$

$\mathrm{Mu}$ Munich, Bayerische Staatsbibliothek, Clm 14219, fols. 7r-15r (tables), 16r-17r (incomplete text); s. XIV/XV

Pr Prague, Národní knihovna České Republiky, XııI.C.17 (2292), fols. 138r-143v (tables), 144r-145r (text); s. XIV/XV

Although the degree of variance between them is considerable, it is possible to group the extant witnesses into two basic categories corresponding to two different versions of the accompanying text. The version attested in manuscripts $A u, B a$, and $M u$ (where the text breaks off halfway into chapter 5 ) is more than twice as long as that preserved by the remaining witnesses and may with good reason be assumed to be the original version of the text. It offers crucial additional information not found in the shorter version, for instance concerning the work's date (1366) and the author's place of writing and region of origin

$9 \quad$ Lynn Thorndike and Pearl Kibre, A Catalogue of Incipits of Mediaeval Scientific Writings in Latin, rev. ed. (Cambridge, MA, 1963), cols. 175, 1229. $A u, B a, E r$, and $K r 2$ were first listed by Ernst Zinner, Verzeichnis der astronomischen Handschriften des deutschen Kulturgebietes (Munich, 1925), 37 (no. 670), 382 (nos. 12486-9o), 394, 540-541. Another copy recorded by Zinner (no. 12487), MS Königsberg, Universitätsbibliothek, 1781, nr. 20-21, was presumably destroyed in the Second World War. Mss Kr and $P r$ were first noted in Sönke Lorenz, "'Studium Generale Erfordense': Neue Forschungen zum Erfurter Schulleben," Traditio, 46 (1991), 261-289, at 281-282 (with n. 110). 
(see below). ${ }^{11}$ Manuscript $B a$ (fol. ır) carries an owner's note informing us that the book in question once belonged to a "Friar Heinrich, apothecary, priest and monk" (Libellus ... fratris Hainrici appotheggarii, presuiteri et monachi). It is unclear whether there is any connection between this individual and the fact that the tables of the shorter versions of $B e$ (fol. 122r) and $K r 2$ (fol. 92r-v) are referred to as Tabule apothekarii, or whether that label was merely there to signal the tables' usefulness for medical purposes. ${ }^{12}$

A more dependable claim, made in the colophon of $K r 2$ (fol. 92v), is that the work was completed in the city of Erfurt, whose studium generale was an important centre for the study of astronomy in mid-fourteenth century Central Europe. This claim is confirmed indirectly by the preface of Conjunctions, which opens with an invocation mentioning Saint Martin, Erfurt's patron saint, ${ }^{13}$ and more directly by chapter 2 of the long version, which informs us that the tables for mean syzygy were cast for the meridian of Erfurt. ${ }^{14}$ The same meridian was also used for the tables serving the mean longitudes of the Moon, as pointed out in chapter 4 , where the author offers the additional information that Erfurt's meridian differs only a little from that of Augsburg, "from which diocese I hail [...], although Augsburg lies further south [than Erfurt]."15 Further place names are mentioned in chapter 6 , which provides the reader with instructions on how to adapt the tables before them to different localities:

He who wishes to adjust these [conjunction times] to a different place must consider if [this place] is further east or west than Erfurt and add to the time of the conjunction as many hours or fractions of hours as [this place] is further east, [or] subtract as many as it is further west. For

For the date, see $A u$, fols. $36 v-37$ r: "Si ergo annis Domini propositis 1366, in quo composui presens opusculum, velim scire secundam coniunctionem eiusdem anni, subtraham ab annis propositis 136 o et remanent 6 anni cicli magni, qui est 76 annorum." The same passage appears in $B a$, fol. 74 rb.

Lorenz, "'Studium Generale Erfordense',', 282-283, was justified in rejecting Zinner's attempt to attribute the work in $\mathrm{Kr} 2$ to a certain Conradus Apothecarius. Cf. Zinner, Verzeichnis, 37 (nos. 670-671), 394. The manuscript in Torun mentioned by both scholars as lost is in fact identical with $B e$.

13 Sönke Lorenz, Studium Generale Erfordense: Zum Erfurter Schulleben im 13. und 14. Jahrhundert (Stuttgart, 1989), 6; Lorenz, "'Studium Generale Erfordense', 282.

$A u$, fol. 35v: "Et constitui has tabulas super meridianum civitatis Erfordiensis, cuius longitudo est a vero occidente 27 graduum." See also $B a$, fol. $71 \mathrm{vb} ; \mathrm{Mu}$, fol. $16 \mathrm{r}$.

$M u$, fol. 17r: "Notandum autem quod radices medii motus lune sunt constitute super meridianum civitatis Erfordiensis et ad meridiem ultimi diei Decembris. Et ergo inventio motus lune veridica est pro meridie civitatis predicte, a cuius civitatis meridiano civitas Augusta, ex qua diocisi ego sum, modicum distat, quamvis Augusta sit plus declivis ad austrum." See also $B a$, fol. 73 ra. The reference to Augsburg is missing from $A u$, fol. 36 r. 
example: Rome is further east than Erfurt by about 34 minutes of the hour. And Salzburg is further east than Erfurt by 10 minutes of the hour. And Paris is further west than Erfurt by 16 minutes. And this distance in time can be assessed based on the terrestrial distance, by counting 1 minute of the hour for every 4 German miles towards the east or west. For 16 German miles correspond to one degree in the heavens, as I have found from experience [ut experimentaliter inveni], and to 1 degree that is traversed at the equator correspond 4 minutes of the hour. Using this principle, one will accordingly be able to investigate the distance in time between two places with sufficient accuracy. ${ }^{16}$

As can be seen, the equivalence between $1^{\circ}$ and 16 German miles is here backed up with an explicit appeal to first-hand experience. Another striking feature of this passage is the way it seems to apply the said relation to all longitudinal distances regardless of latitude. The fact that a degree of longitude at the parallels of Erfurt, Paris, or Salzburg will be much shorter than the 16 German miles measured at the equator is here conveniently ignored. We observe the same type of shortcut in a so-called Lunarius written in Stendal and dated 1374, which is a more elaborate representative of the same astronomical genre as Conjunctions. ${ }^{17}$ Another contemporary example is the Kalendarium magistri Hainrici Soldri, whose columns display the times - precise to the nearest second - of all mean conjunctions of the Sun and Moon during the four 19-year cycles from 1361 to 1436 , pointing to a composition in the 136 os or early 1370 s

$16 \quad B a$, fol. 76rb-va: "Qui vero voluerit ea rectificare pro alio loco, considerat si sit orientalior vel occidentalior quam Erdfordia, et quanto ad horas vel ad fractiones horarum est orientalior tantum addat super tempus coniunctionis hic inventum, in quanto occidentalior, tantum subtrahat [ms.: subtrahas]. Verbi gratia: Roma est orientalior Erdfordia vere 34 minutis unius hore et Salczburga orientalior [ms.: occidentalior] quam Erdfordia 10 minutis unius hore et Parisius occidentalior quam Erdfordia 16 minutis. Et hec distantia in tempore poterit perpendi ex distancia in terris [ms.: tertiis], computando pro quibuslibet quatuor miliaribus theutonicis diem(?) versus orientem vel occidentem unum minutum hore. Nam 16 miliaria theutonica <cor>respondent uni gradui in celo, ut experimentaliter inveni, et uni gradui equinoctiali<ter $>$ pertransitum correspondent quatuor minuta hore. Unde hoc modo poterit distantia duorum locorum quo [ms.: qua] ad tempus satis prope indagare." See also $A u$, fol. 38 r.

MS Vatican City, Biblioteca Apostolica Vaticana, Pal. lat. 1353, fols. 8v-34rb, at 34ra: "Si autem vis adaptare presens opus meridiano alicuius civitatis que non est posita in tabula regionum tunc oportet te scire quantum civitas proposita distat a civitate Stendal, scilicet quot miliaribus theutonicis distat a Stendal versus orientem vel occidentem perducans lineam. Et numerum illorum miliarum quere in tabula que intytulatur 'expansorum', si ista miliaria finiunt pauciora quam sedecim, si autem fuerint 16 vel plus, tunc quere ea in tabula que intytulatur 'collectorum'." The tables referenced here appear ibid., fol. 2gr-v. 
(i.e., during the first 19-year cycle). ${ }^{18}$ Its author chose to calculate these conjunction times by adjusting the Alfonsine Tables to the meridian he assumed to be passing through Padua and Salzburg, which he located o;22h east of Paris. ${ }^{19}$ As with Conjunctions and the Lunarius, the Kalendarium contains instructions on how to adjust its data to cities located on other meridians:

He who wants to know these conjunctions for other meridians should consider whether his location is further east or west than Padua or Salzburg. And if he is further west, then he must subtract 1 minute of the hour for every 4 German miles, but if he is further east, he must add [this amount], and he will have [the result] for his location with respect to the meridian of the place in which he lives or with respect to the one he desires to know. ${ }^{20}$

The similarities between these instructions and those included in Conjunctions are readily apparent. Both texts state that 4 German miles are equivalent to o; $1 \mathrm{~h}$, which is $\circ ; 15^{\circ}$ of a diurnal revolution and hence amounts to saying that $1^{\circ}$ equals 16 German miles. They also both mention the city of Salzburg, but offer different estimates for its location relative to Paris. In Conjunctions, the stated distances for Paris-Erfurt and Erfurt-Salzburg imply a total distance of o; $16 \mathrm{~h}+0 ; 1 \mathrm{~h}=0 ; 26 \mathrm{~h}$. By contrast, the Kalendarium places Salzburg's meridian only o;22h further east than Paris, which assumption is also implicit in the conjunction times recorded in the relevant tables. Compared to the Alfonsine Tables, which were originally cast for the meridian of Toledo, these conjunctions

18 This work was studied by Karl Mütz, "Der Kalender des Magister Hainrich Solder: Ein Reformwerk 180 Jahre vor Papst Gregor XIII," Rottenburger Jahrbuch für Kirchengeschichte, 18 (1999), 167-185. For more on this genre of calendars, see C. Philipp E. Nothaft, "Medieval Astronomy in Catalonia and the South of France: The 'Improved' Lunar Kalendarium of Friar Raymond (Ramon) Bancal (ca. 1311) and Its Predecessors," Llull, 38 (2015), 101-25; idem, Scandalous Error: Calendar Reform and Calendrical Astronomy in Medieval Europe (Oxford, 2018), 164-183, 195-196.

19 MS Rottenburg am Neckar, Diözesanbibliothek, H 15, fol. 8ra: "Et nota quod hee coniunctiones medie constitute sunt super meridiem Baduanum, qui est idem cum meridiano civitatis Saltzburge, distans a meridiano Parysiensi ad orientem 22 minutis horarum fere secundum tabulas Alphontii." The manuscript page is reproduced as "Abb. 6" in Mütz, "Der Kalender."

20 MS Rottenburg am Neckar, Diözesanbibliothek, H 15, fol. 8r: "Item qui vellet scire has coniunctiones pro aliorum meridianorum, consideret si locus suus sit orientalior vel occidentalior quam Badua vel Saltzburga. Et si fuerit occidentalior, tunc pro quibuslibet quatuor miliaribus theutunicis subtrahat unum minutum hore, si vero fuerit orientalior, addat, et habebit ad locum suum de respectu meridiani istius loci in quo habitat vel respectu cuius hoc noscere cupiebat." 
exhibit an addition of 1;10h, suggesting that Salzburg lies 17;30 further east than Toledo. This gap is just $5 ; 30^{\circ}=0 ; 22 \mathrm{~h}$ greater than the most commonly attested late-medieval value for the longitude difference between Toledo and Paris, which is $12^{\circ}=0 ; 48 \mathrm{~h} .{ }^{21}$

Despite this discrepancy of $0 ; 4 \mathrm{~h}$ or $1^{\circ}$, there are good reasons for assuming that both works were composed by one and the same author: Heinrich Selder, a Swabian astronomer with connections to the University of Paris. ${ }^{22}$ Selder's authorship of the Kalendarium is revealed by the table of contents prefacing the only known copy, where his name appears in a slightly garbled form (Hainrici Soldri). ${ }^{23}$ Another, previously unnoticed, witness to his scientific activities is the astronomical and astrological miscellany MS Copenhagen, Det Kongelige Bibliotek, Add. $4472^{\circ}$, which was assembled in the second half of the fourteenth century. ${ }^{24}$ The words hec Henricus Selder are here written next to a brief text that accompanies a table displaying the dimensions of the seven climates in the northern hemisphere (fol. 136ra). Contrary to what the misleading formula in the canon to his Kalendarium might have us suspect, Selder here shows a clear grasp of the implications of the spherical-Earth model for the distances between meridians at different latitudes. Using a simple trigonometric formula, he calculates that $180^{\circ}$ of longitude will reduce from 288 o German miles at the equator to only $1818 ; 1,5^{2}$ German miles at a latitude of $50 ; 30^{\circ}$ (the northern border of the seventh climate) ${ }^{25}$ As with the other sources discussed

$21 \quad$ For the standard interval of o; $48 \mathrm{~h}$, see Richard L. Kremer and Jerzy Dobrzycki, "Alfonsine Meridians: Tradition versus Experience in Astronomical Practice c. 1500," Journal for the History of Astronomy, 29 (1998), 187-199, at 194; C. Philipp E. Nothaft, "Jean des Murs's Canones Tabularum Alfonsii of 1339," Erudition and the Republic of Letters, 4 (2019), 98-122, at 102.

C. Philipp E. Nothaft, "Vanitas vanitatum et super omnia vanitas: The Astronomer Heinrich Selder and a Newly Discovered Fourteenth-Century Critique of Astrology," Erudition and the Republic of Letters, 1 (2016), 261-304.

23 See "Abb. 1" in Mütz, "Der Kalender."

24 I shall discuss this manuscript and its relation to Selder in greater detail in a future publication.

25 MS Copenhagen, Det Kongelige Bibliotek, Add. $4472^{\circ}$, fol. 136ra-b: "Ego volui scire longitudinem finis septimi climatis in miliaribus teutonicis in superficie terre et propter $<$ hoc $>$ prius investigavi medietatem equinoctialis in terra sive longitudinem terre $a b$ oriente in occidentem, et sunt tot milia: 288 o. [...] Deinde multiplicavi sinum rectum in 288o et provenerunt tot secunda: 395694720, que divisi per 6o gradus et inveni 6544912 secunda, que reduxi ad fractiones grossiores et ad integra et inveni 1818 miliaria et unum minutum et $5^{2}$ secunda. Dico tantam esse lineam terminantem septimum clima ab oriente in occidentem." The modern approach to this calculation would be to multiply the 288 o German miles corresponding to $180^{\circ}$ on the equator by the cosine of the targeted latitude, whereas Selder swaps $\cos \left(5 \circ ; 30^{\circ}\right)$ for $\sin \left(90^{\circ}-5 \circ ; 30^{\circ}\right)$. His result differs from the correct one (1831.905 ... German miles) owing to a corrupt digit in the penultimate step of 
so far, both the text and the preceding table are predicated on the assumption that the circumference of the Earth is $16 \times 360=5760$ German miles.

Heinrich Selder's name makes a further appearance in manuscript $A u$, where a set of computistical tables attributed to him precedes the beginning of Conjunctions. ${ }^{26}$ The case for seeing in Conjunctions another work by Selder is greatly strengthened by the similarities between it and the Canones for the Alfonsine Tables he is known to have composed in 1365 , just one year prior to Conjunctions. ${ }^{27} \mathrm{As}$ is the case with the latter work, the Canones begin with an invocation mentioning St Martin next to God and the Virgin Mary, once again suggesting that they were written in an Erfurt context. ${ }^{28}$ The same suspicion is raised by a passage detailing how to determine the longitudinal distance between two cities, on which more will be said below. Selder here uses Erfurt as his chief example, noting that it lies $16^{\circ}=1 ; 4$ h east of Toledo. He informs us that Lübeck has nearly the same longitude, although it is found further to the north. Likewise, Bamberg, Nuremberg, and Augsburg all seem to share Erfurt's meridian, but are located further south. ${ }^{29}$ This is rather reminiscent of the way in which the relative positions of Erfurt and Augsburg are expressed in the long version of Conjunctions. ${ }^{30}$

Further reasons for attributing Conjunctions to Selder are furnished by an anonymous Tractatus de tempore dominice annunciationis, nativitatis et passionis, which has come down to us in a manuscript from Tegernsee Abbey, copied in the second quarter of the fifteenth century. ${ }^{31}$ The author of this Tractatus

the calculation (6544912 instead of 6594912 seconds). Had he used an uncorrupted value, he could have obtained 1831;55,12 $=1831.92$ German miles.

26 See the tables and corresponding canons in $A u$, fols. $28 \mathrm{r}-29 \mathrm{v}$. The heading on fol. $28 \mathrm{r}$ says "Tabula Dionysii vel saltem sibi similis, quia magister Heinricus Selder eam fecit."

27 For more on Selder's Canones, see Nothaft, "Vanitas vanitatum," 262-267.

28 MS Erfurt, Universitäts- und Forschungsbibliothek, Dep. Erf. CA $2^{\circ} 37$, fols. 63 bisr- $85 \mathrm{v}$, at 63 bisr: "In nomina domini misericordis et pii et beatissime intacte virginis Marie et beati Martini. Amen." I here quote from the earliest known copy of the Canones, which was completed in Paris on 14 December 1377.

29 Heinrich Selder, Canones, diff. 2, c. 3, MS Erfurt, Universitäts- und Forschungsbibliothek, Dep. Erf. CA $2^{\circ} 37$, fol. 67ra: "Erfordia distat a Toleto versus orientem 16 gradus et hoc est una hora equalis et 4 minuta unius hore, sicut per secundum modum comprehensum est. A quo meridiano Erfordensi civitas Lubek, licet sit septentrionalior, modicum distare videtur. Item civitas Babenberg et Nuremberg et civitas Augusta ab eodem meridiano nichil distare videntur, licet meridionaliores reperiantur."

30 See n. 15 above.

$31 \quad$ MS Munich, Bayerische Staatsbibliothek, Clm 18298, fols. 1r-34v. Excerpts from the same text appear in MS Vatican City, Biblioteca Apostolica Vaticana, Pal. lat. 1354, fols. 33r, 96v, 166v, 214va-243va. 
gives 1371 as the year in which he began writing, ${ }^{32}$ but it is evident that he was still working on parts of the text in $1378 .{ }^{33}$ Owing to some very striking doctrinal parallels between this work and the Canones of 1365 , it appears highly likely that the Tractatus is in fact another work by Heinrich Selder. ${ }^{34}$ As for connecting threads between the Tractatus and Conjunctions, one may begin with the fact that the Tractatus' author makes several astronomical calculations for the city of Augsburg, which he locates "in our diocese" while noting that its meridian lies about one-quarter of an hour further east than that of Paris. ${ }^{35}$ This is congruent with the long version of Conjunctions, which puts Erfurt o;16h east of Paris while claiming that Augsburg, "from whose diocese I hail," deviates only little from Erfurt's longitude. ${ }^{36}$ Another salient parallel between the two works consists in their respective treatment of the date of Christ's Passion. In the long version of Conjunctions, there is a whole section in which the author uses his conjunction tables as well as the Jewish calendar to calculate the year and date of the crucifixion, concluding that this event happened on 3 April AD $33 .{ }^{37}$ The same result is achieved in the Tractatus, whose author has an identical way of employing the Jewish calendar in support of his chronological argument. ${ }^{38}$

More relevant to our present purposes is a passage in the Tractatus that establishes the distance Jesus Christ had to travel when he ascended into heaven following his Resurrection. This distance is assumed to be equal to the distance from the centre of the world to the convex surface of the sphere of fixed stars. Based on the values in al-Farghānī's Elements of Astronomy, ${ }^{39}$ Selder gives this distance as 20,110 terrestrial radii and goes on to specify that one degree in the heavens corresponds to 16 German miles on Earth. From this he infers that the Earth has a circumference of 576 o German miles, an approximate diameter of

32 MS Munich, Bayerische Staatsbibliothek, Clm 18298, fol. 32vb.

33 Ibid., fol. $28 \mathrm{v}$. A definite terminus ad quem for the work as a whole is posed by the JupiterSaturn conjunction of 10 April 1385 mentioned ibid., fol. 12r.

34 These parallels are discussed in Nothaft, "Vanitas vanitatum," 272-279.

35 MS Munich, Bayerische Staatsbibliothek, Clm 18298, fol. 32ra: "Sed secundum tabulas Alphonsi erat illa coniunctio per 28 minuta hore ante meridiem predicte ferie quinte respectu meridiani civitatis Auguste diocesis nostre, que distat a meridiano Parysiensi versus orientem circa quartam partem unius hore."

36 See $n .15$ above.

$37 \quad A u$, fols. $37 \mathrm{v}-38$ r; $B a$, fols. 75 va- 76 rb.

38 MS Munich, Bayerische Staatsbibliothek, Clm 18298, fols. 31va-32rb.

39 al-Farghānī, Liber zo differentiarum, trans. John of Seville, diff. 21, ed. Francis J. Carmody, Al Farghani Differentie (Berkeley, CA, 1943), 38-39. 
$183^{3 / 4}$ German miles, and an approximate radius of 916 1/3 German miles. ${ }^{40}$ His justification for using this value is entirely empirical:

This correspondence between a portion of the Earth and one degree in the heavens is what our experimenters [nostri experimentatores] found and it is close to correct, as I have also experienced myself, even though others report that they found this to be otherwise. And I do not doubt that you yourself, if you were to investigate this, would disagree with these others. ${ }^{41}$

Selder here asserts that the equivalence of $1^{\circ}$ and 16 German miles accords with his own experience (sicut et ego expertus sum), which seems to echo a passage (ut experimentaliter inveni) in the long version of Conjunctions. ${ }^{42}$ In contrast to the latter, however, the passage in the Tractatus also refers to the empirical work carried out by certain predecessors, nostri experimentatores. These experimentatores, who apparently were the first to establish the stated equivalence, are here being contrasted with certain contemporary scholars who make divergent claims about the length of a degree. It is evident from his own words, however, that Selder regarded these claims to be incorrect.

While the Tractatus here merely alludes to the existence of alternative views, we get a clear example of one such alternative in the annotations that cover most of the marginal space surrounding the passage in the Tegernsee manuscript. The annotator in question appears to have been Johannes Keck, monk and prior of Tegernsee Abbey during the 1440 s, ${ }^{43}$ who took a keen

40 MS Munich, Bayerische Staatsbibliothek, $\mathrm{Clm}$ 18298, fols. 32rb-va: "Cum autem uni gradui in celo correspondeant in terra 16 miliaria Theutonica, continebit maximus cingulus terre, id est circumferencia eius seu periferia, 576o miliaria Theutonica, quod liquet multiplicando 16 per 36 o. Itaque iuxta regulam qua dyameter extrahitur ex circumferencia nota continebit dyameter terre et spissitudo eius 1832 miliaria Theutonica et fere 3 quartas unius miliaris, quare semidyameter terre, id est spissitudinis medietas, continebit 916 miliaria Theutonica et fere tertiam partem unius miliaris. Si quis igitur in miliaribus Theutonicis voluerit aliquam predictarum altitudinum cognoscere, multiplicet illam in semidyametrum terre iam notam, id est in 916 miliaria et fere tertiam partem unius miliaris, et habebit quesitum."

41 Ibid., fol. 32va: "Hanc quidem correspondenciam portionis terre uni gradui in celo invenerunt nostri experimentatores et est prope verum, sicut et ego expertus sum, licet alii aliter narrant eam se invenisse. Et tu ipse, si investigares eam, non dubito quin aliis discordares."

42 See $n .16$ above.

43 On Keck, see C. Philipp E. Nothaft, "Johannes Keck, das Konzil von Basel und der vergessene Osterstreit des Jahres 1444," Deutsches Archiv für Erforschung des Mittelalters, 71 (2015), 105-147, at 112-117. 
interest in some of the chronological arguments contained in Selder's Tractatus. In a long gloss in the bottom margin of fol. 32r, Keck operates with the Eratosthenian equivalence of $1^{\circ}=700$ stades. He follows classical Roman conventions in accepting that there are 125 paces for every stade and 8 stades for every Italian mile. The Italian mile accordingly holds 1000 paces, whereas the German mile contains 4800 paces, such that one degree of latitude comprises 18 German miles and another 1100 paces. ${ }^{44}$ Adding further marginal notes, Keck argues that Selder's 16 German miles per degree are equivalent to only 614 stades and 50 paces, which is $2{ }^{11} / 48$ German miles below his own estimate..$^{45}$ It does not appear to be the case, however, that this disagreement between Selder and his annotator was merely based on different definitions of the length of a German mile. We learn more about Selder's idea of this length from the following passage, which immediately precedes the one mentioning nostri experimentatores:

The German mile, as I use it in the present context, consists of 60 acres and the acre of 32 rods, whereas the rod [consists] of 5 paces, and [the German mile] is of such length that a pedestrian walking at a common pace completes one in $1 \frac{1 / 2}{2}$ equinoctial hours, but a horse in 1 [hour]. And one of our miles makes about 2 leagues in France and roughly 5 miles in Italy. ${ }^{46}$

At first glance, it may seem confusing to find the total number of paces in a German mile given as $60 \times 32 \times 5=9600$ paces, as this is twice the length accepted in Keck's annotations. The problem disappears, however, if we make

44 MS Munich, Bayerische Staatsbibliothek, Clm 18298, fol. 32v: "Nota alii communiter ponunt 700 stadia terre correspondere uni gradui in celo et illa faciunt precise miliaria theutonica 18 et passus 1100. Habet autem miliare theutonicum passus 4800 . Nota [...] pedes 5 faciunt passum; passus 125 faciunt stadium; octo stadia faciunt miliare ytalicum; duo miliaria italica faciunt leucam."

45 Ibid., fol. 32va: "Discordat quippe ab aliis deficiendo 85 stadiis et 75 passibus a $700^{\text {tis }}$ stadiis que faciunt 2 miliaria theutonica et $11 / 48$." Ibid.: "Et sic deficit in duobus miliaribus theutonicis ab aliis et $11 / 48$, que sunt fere quarta pars miliaris theutonici." Ibid., fol. $32 \mathrm{v}$ : "Nota 16 miliaria theutonica faciunt 615 stadia minus 75 passibus, vel 614 stadia et $5^{\circ}$ passus quorum unus est de quinque pedibus."

46 Ibid., fol. 32va: "Constat autem miliare theutonicum, ut eo in proposito utor, ex 60 longitudinibus agrorum et longitudo agri ex 32 perticis et pertica vero ex quinque passibus [before correction: pedibus]. Et est tante longitudinis quod communi ambulatu pedester quidem perficit unum in hora equali et semis, equus [after correction: equester] autem in una. Et unum nostrum miliare facit quasi duas leucas in Gallia et fere 5 miliaria in Ytalia." A modified version of the same passage appears in MS Vatican City, Biblioteca Apostolica Vaticana, Pal. lat. 1354, fol. 166vb. 
the distinction Keck recommends in a gloss on the same page: that between common paces (passus vulgares) of $2^{1 / 2}$ feet and so-called geometrical paces (passus geometrici) of 5 feet. Since the relation between rods and feet remains stable, a rod will contain 5 paces of the common variant, but only $21 / 2$ of the geometrical one. ${ }^{47}$ Selder's equation of a rod with 5 paces hence shows him to be using the common pace, meaning that his value for the German mile was no different from the mile of 4800 geometrical paces assumed in Keck's annotations. If one follows these annotations in counting 1000 geometrical paces for each Italian mile, the German mile jointly used by Selder and Keck turns out to be close to, but not quite the same as 5 Italian miles. Keck or some other annotator underlined this very point by adding minus 200 passibus to Selder's fere 5 miliaria. ${ }^{48}$

According to the metrological studies of Pierre Hermann, the late-medieval German mile fluctuated at $8.5 \mathrm{~km} \pm 1.5 \mathrm{~km},{ }^{49}$ which suggests $7 \mathrm{~km}$ as a lower boundary and $10 \mathrm{~km}$ as the upper one. We would come very close to the lower boundary if we were to treat an Italian mile as identical with the ancient Roman mile of $1.48 \mathrm{~km}$. The correspondence of 4800 paces $=4.8$ Italian miles $=1$ German mile would then imply that 1 German mile had a length of $7.104 \mathrm{~km}$. It is not unlikely that Selder's German mile approximated this value. After all, his own words, if read in the light of Keck's glosses, imply that 1 German mile equals 4800 geometrical paces $=24000 \mathrm{ft}$. If we are here dealing with the Roman foot of $0.296 \mathrm{~m}$, as seems likely given its prevalence in pre-metrical land measurement, ${ }^{50}$ this would again give us $7.104 \mathrm{~km}$ for each German mile. A possible hint that this is indeed an adequate estimate comes from Selder's claim that the German mile he uses in his calculations is about equal to the distance a pedestrian covers in one and a half hours, whereas a person on

47 MS Munich, Bayerische Staatsbibliothek, Clm 18298, fol. 32v: "Nota duplices sunt passus, scilicet vulgares et geometrici. Passus vulgaris constat duobus pedibus et dimidio et talium passuum 5 faciunt perticam. Passus autem geometricus constat 5 pedibus et sic est duplus ad vulgarem." Above this note is written: "Notandum passus accipitur pro quinque pedibus communiter, hic autem pro duobus pedibus et semis. Unde constat quod pertica continet pedes 12 et $1 / 2$, id est duos passus et semis communiter dictos." In a note in the lower margin of the same page, Keck points out the following with regard to his own use of the pace: "Nota quod passus illi quorum 5 faciunt perticam sunt precise subduplo ad illos quos iam descripsimus."

48 Ibid., fol. 32va. The same annotator added "plus 800 passibus" to Selder's "quasi duas leucas," thereby taking into account that 4800 paces equal 2 leagues +800 paces (since 1 league $=2$ Italian miles $=2000$ paces $)$.

49 Pierre Herrmann, "Les lieues et les milles utilisés depuis le Moyen Age," Mediaevistik, 26 (2013), 31-56, at 51 .

$50 \quad$ Elisabeth Pfeiffer, Die alten Längen- und Flächenmasse und ihr Ursprung, geometrische Darstellungen und arithmetische Werte, 2 vols. (St Katharinen, 1986), 1:214-322. 
horseback would only need one hour. It is of course difficult to determine what Selder may have regarded as the normal travel speed for either people or horses. Still, it may be worth observing that $7 \mathrm{~km} / \mathrm{h}$ is about the average speed of a horse moving with a walking gait. As for humans, to cover $7 \mathrm{~km}$ in $1 \frac{1 / 2}{2}$ hours by foot would require a brisk, but feasible, walking pace of $42 / 3 \mathrm{~km} / \mathrm{h}$. If Selder really worked with a German mile of $7.104 \mathrm{~km}$, his value for the circumference of the Earth would have been $7.104 \mathrm{~km} \times 5760=40,919.04 \mathrm{~km}$, which exceeds the $c .40,075 \mathrm{~km}$ currently measured for the Earth's circumference by only about 2 per cent.

It remains to be asked how Heinrich Selder and the unknown experimentatores that came before him managed to arrive at their convention of counting 16 German miles for each degree along a great circle. To date I have found no fully convincing way in which this relation could have been derived from the transmitted ancient values. At most, one might argue that it came about as a very crude derivation from the Eratosthenian $1^{\circ}=700$ stades. We have seen that Eratosthenes' degree is equivalent to $87^{1 / 2}$ Italian miles, which Johannes Keck equated with $18^{11 / 48}$ German miles. Conceivably, the notion that $1^{\circ}$ equals 16 German miles may have originated from rounding $87^{1 / 2}$ Italian miles to 80 Italian miles. Combined with an assumed equivalence of 5 Italian miles with 1 German mile, this would yield the required $80 \div 5=16$ German miles per degree. Yet to argue this way would be to ignore that the Tractatus treats this equivalence of 5 Italian miles $=1$ German mile as approximate rather than exact (fere 5 miliaria). More to the point, it would also be tantamount to a dismissal of the remarks made by Heinrich Selder, both there and in Conjunctions, about his experiential basis for assuming that there are 16 German miles to the degree.

The notion that fourteenth-century astronomers would have made efforts to measure empirically the length of a terrestrial degree has so far found no place in the historiography of medieval science. On the contrary, Durand's verdict that " $[t]$ here is no evidence that an independent calculation of the length of a degree was undertaken during the Middle Ages" appears to remain the communis opinio. ${ }^{51}$ It is certainly true that medieval European sources do not reveal anything about organized, state-funded measurements of the length of a degree, of the sort that was reportedly carried out during the reign of Caliph al-Ma'mūn $(813-833) .{ }^{52}$ Yet it should also be clear that the means to test,

$51 \quad$ Durand, Vienna-Klosterneuburg Map Corpus, 169.

$5^{2} \quad$ See F. Jamil Ragep, Nașīr al-Dìn al-Ṭussìs 'Memoir on Astronomy' (al-Tadhkira fì 'ilm al-hay'a), 2 vols. (New York, 1993), 2:501-510, and David A. King, "Too Many Cooks...: A New Account of the Earliest Muslim Geodetic Measurements," Suhayl, 1 (2000), 208-241, where 
confirm, or revise existing estimates of the length of a degree of latitude were within the reach of Latin astronomers in Selder's period. All they needed to make such a measurement was a distance estimate between two localities of known latitude, provided these localities occupied the same meridian.

How such a distance estimate was arrived at - whether it was newly measured or derived from an existing tradition - is ultimately less important than the means by which late-medieval astronomers determined the latitudes and longitudes of the places they were interested in. Examples of newly established European coordinates are documented in numerous Latin sources of the twelfth to fifteenth centuries, usually in the context of astronomical tables, leaving us in no doubt that the pertinent techniques were used at least occasionally. ${ }^{53}$ Heinrich Selder himself is a significant case in point, for instance when he tells us that the city of Rome has a northern latitude of $42^{\circ}$, "as I have experienced" (ut expertus sum). He additionally states that Rome's meridian lies $8 ; 28 \mathrm{~h}\left(=127^{\circ}\right)$ from the point designated as "true East,"54 which implies a longitude $24 ; 30^{\circ}$ east of Toledo. 55 The longitude of the Eternal City is also

the author urges us to treat the reports of this measurements with a healthy dose of scepticism.

53 Some examples are noted in Durand, Vienna-Klosterneuburg Map Corpus, 105-106, 335336. See also Rolando A. Laguarda Trias, La ciencia española en el descrubrimiento de America: las tablas de coordenadas geográficas compiladas en la España medieval (Valladolid, 199o); Patrick Gautier Dalché, "Connaissance et usages géographiques des coordonnées dans le Moyen Âge latin (du Vénérable Bède à Roger Bacon)," in Louis Callebat and Olivier Desbordes, eds., Science antique, science médiévale (autour d'Avranches 235): actes du Colloque International (Mont-Saint-Michel, 4-7 septembre 1998) (Hildesheim, 2000), 401-436, repr. as ch. 14 in idem, L'espace géographique au Moyen Âge (Florence, 2013); Gautier Dalché, "'Quando vuoli travare la longitudine d'alchuna citta da Occidente, guarda nel mappamondo da Maiolica...': la mesure des coordonnées géographiques selon Paolo dell'Abbaco," Micrologus, 19 (2011), 151-199; Gautier Dalché, "La Terre dans le cosmos," in idem, ed., La Terre: connaissance, représentations, mesure au Moyen Âge (Turnhout, 2013), 161-257, at 219-241.

54 MS Munich, Bayerische Staatsbibliothek, Clm 18298, fol. 6rb-va: "Est autem Roma posita in Europe in linea transeunte ab oriente in occidentem per medium quinti climatis, distans ab equinoctiali circulo 42 bus gradibus fere, ut expertus sum, unde et quintum clima ab ea 'Dyarome', penultima producta, nominatur. Cuius quidem Rome meridies distat a puncto veri orientis 8 horis equalibus et 28 minutis unius hore. Unde per duas horas et 28 minuta est propior occidenti quam orienti."

55 Medieval astronomical sources place Toledo $28 ; 30^{\circ}$ from the true West, which by definition was located $180^{\circ}$ from the true East. For the distance Toledo-Rome, this gives us $180^{\circ}-127^{\circ}-28 ; 30^{\circ}=24 ; 30^{\circ}$. On the geographic notion of "true" East and West, see John Kirtland Wright, "Notes on the Knowledge of Latitudes and Longitudes in the Middle Ages," Isis, 5 (1923), 75-98, at 90-97; Mercè Comes, "The 'Meridian of Water' in the Tables of Geographical Coordinates of al-Andalus and North Africa," Journal for the History of Arabic Science, 10 (1992-1994), 41-51. 
raised in Conjunctions, where Selder informs us that the distance between Erfurt and Rome is 8;30 $=0 ; 34 \mathrm{~h}^{\circ 6}$ This would put Erfurt's meridian $16^{\circ}$ east of Toledo, a value that receives confirmation both from the astronomical data in Conjunctions and from an explicit statement Selder made in his Canones of $1365 \cdot{ }^{57}$

The passage in the Canones is especially valuable for giving us some indication of how Selder went about measuring terrestrial longitudes. In the same chapter, he instructs readers to use an astrolabe to time the beginning of a lunar eclipse in one city and thereby establish its time difference relative to another city - a method he qualifies as reliable and true (certus et verus). ${ }^{58} \mathrm{He}$ immediately goes on to indicate that this same method was used to establish the longitude of Erfurt as $16^{\circ}$ or 1;4h east of Toledo (correct: $\left.15 ; 3^{\circ}\right)$. What follows this revealing statement is a passage already mentioned above, in which Selder nominates Lübeck, Bamberg, Nuremberg, and Augsburg as cities that lie more or less on the same meridian as Erfurt. ${ }^{59}$

It may be more than a coincidence that this passage contains exactly the type of information Selder would have needed to carry out the measurement he later alluded to in Conjunctions, where he claims to have found experimentaliter that there are 16 German miles to one degree of latitude. One specific way he could have found this result is by taking Erfurt and Augsburg, two cities to which he was personally linked, and dividing the number of miles between them by their difference in latitude. To offer a purely hypothetical example of the values that might have been employed: the linear distance between Erfurt and Augsburg is very nearly $290 \mathrm{~km}$, which on a German mile of $7.104 \mathrm{~km}$ would equal approximately 40.8 German miles. Should Selder have operated with a round distance estimate of 40 German miles, he could have straightforwardly arrived at the stated result of $16 \mathrm{German}$ miles per degree if his assumed

$56 \quad$ See $n .16$ above.

57 See $n .29$ above.

58 Selder, Canones, diff. 2, c. 3, MS Universitäts- und Forschungsbibliothek, Dep. Erf. CA $2^{\circ}$ 37, fols. 66vb-67ra: "Et hoc est verum si invenis ambas regiones vel civitates in tabula regionum, et oportet quod tabula regionum sit bene posita, quam tamen minime vidi. Et propter hoc utaris secundo modo et est iste: equa principium eclipsis lunaris per tabulas loci radicum. Postmodum tempore eclipsis lunaris quam per tabulas invenisti sis in civitate ista cuius distanicam queris, et cum luna iam incipit intrare umbram tunc capias altitudinem alicuius stelle fixe in astrolabio super latitudinem tue regionis inscripte ponasque cacumen eiusdem stelle in almucantharat altitudinis sue et invenies tempus quod est elapsum a principio meridiei usque ad illud tempus, sicut expositum est circa astrolabium. Tunc subtrahe minus tempus a maiore et illud quod remanet erit distancia inter duas civitates quesitas et habebis intentum. Et iste modus certus est et verus."

See n. 29 above. 
latitudes for Erfurt and Augsburg were $2 ; 30^{\circ}$ apart. The modern value for Augsburg's latitude is $48 ; 22^{\circ}$, which puts it $2 ; 37^{\circ}$ further south than Erfurt's $5^{\circ} ; 59^{\circ}$. The implied discrepancy of $0 ; 7^{\circ}$ is not especially dramatic and may be compared to Selder's value for the latitude of Rome $\left(42^{\circ}\right)$, which is too high by c. $0 ; 6^{\circ}$.

Again, the numerical details are far less important than the plausibility of the underlying scenario, according to which a fourteenth-century astronomer such as Selder would have been able to find a good approximation to the degree of latitude by comparing the distances and latitudes of places he assumed to lie on the same meridian. If this scenario is plausible, as I believe it is, then the sources discussed in the foregoing may well offer us something new and unexpected: a genuine medieval European value for the circumference of the Earth: $16 \times 360=576$ o German miles. 